\title{
Big Ideas: Annual Report 2012
}

Population Council

Follow this and additional works at: https://knowledgecommons.popcouncil.org/ series_newsletters_annualreports How does access to this work benefit you? Let us know!

\section{Recommended Citation}

"Big Ideas: Annual Report 2012." New York: Population Council, 2013. 


\section{BIG IDEAS}

If we improve adolescent girls' health, keep them safe and in school, and give them critical information and a say in their own lives, they and their families and communities will prosper. The Population Council conducts the world's largest body of research on programs to improve the lives of adolescent girls in the developing world.

Big ideas supported by evidence: It's our model for global change. 



\section{POPULATION COUNCIL POLICY ANALYST}

JUDITH BRUCE WAS AMONG THE FIRST TO

ARGUE THAT ADOLESCENT GIRLS ARE

CENTRAL TO THE WORLD'S SOCIAL, HEALTH, AND ECONOMIC DEVELOPMENT.

In the mid-1990s, many in the development community were skeptical. But a decade and a half later, because of Judith and others like her, we have a clearer picture of the potential of girl-centered policies to reach hundreds of millions of girls at risk of forced marriage, in the path of the HIV epidemic, and under daily threat to their safety.

This year's annual report focuses on the Population Council's work to improve policies and programs for the poorest girls in the poorest communities so that they may lead themselves and their communities out of poverty. Fifteen years ago, Judith wrote, "Global thinkers are puzzled, looking for points of reference and leverage to understand and shape the future. They identify power elites and influential individuals. Appearing on none of these power lists is one of the potentially most influential figures in the developing world: the 12-year-old girl. ... In the next few years, this 12-year-old girl will either abandon or continue her schooling, be pushed into marriage and childbearing, or develop a sense of proud ownership of her physical self and make independent decisions about her lifetime partner. She will either struggle in poverty or find a socially productive livelihood, submit to a faceless life or thrive as an individual, making her contribution to the world. As her future is reconfigured, so is ours."

The Uncharted Passage-the landmark 1998 book Judith coauthored with Council researcher Barbara Mensch and Center for Health and Gender Equity researcher Margaret Greene-helped transform thinking about the social, health, and economic dimensions of girls' lives. It inspired our partners as well as the next generation of Population Council researchers like Annabel Erulkar, K.G. Santhya, and Karen Austrian. They are leading projects in Ethiopia, India, and Zambia to design and evaluate programs that give girls the knowledge, skills, and social connections they need to thrive and to give policymakers research results they can use to improve programs and efficiently allocate resources.

What were epiphanies in 1998-engage girls before puberty; reach out-of-school girls; and give girls the skills, knowledge, 


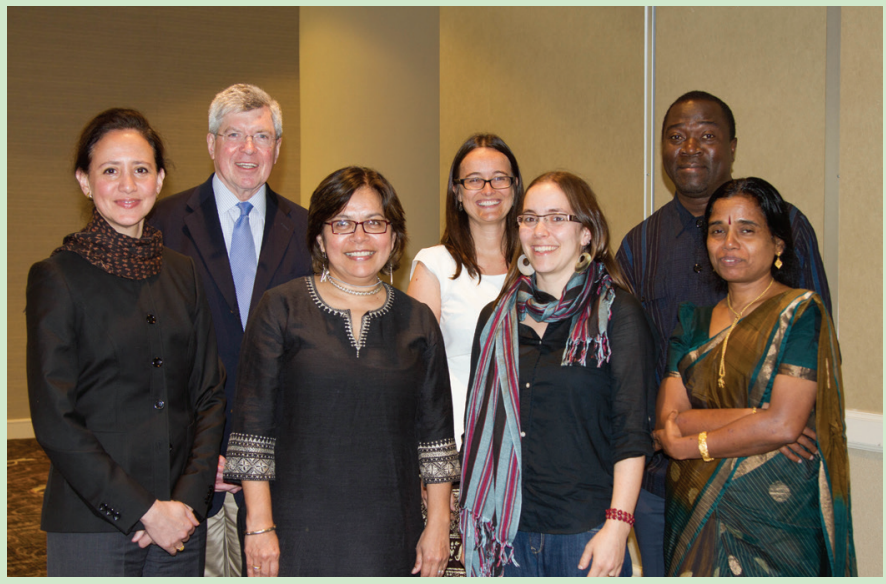

Population Council researchers around the world are generating evidence to improve girlcentered programs and policies.

Left to right: Annabel Erulkar (Ethiopia), Peter Donaldson, Sajeda Amin (Bangladesh), Alejandra M. Colom (Guatemala), Karen Austrian (Kenya and Zambia), Babatunde A. Ahonsi (Nigeria), and K.G. Santhya (India). and I.D. cards they need to protect themselves-are now conventional wisdom. In Rwanda, the Council laid the foundation for the government's commitment to a national program to reach all girls by age 12 with mentors, safe places to gather with friends, and information about health and money management. In Ethiopia, the Council's research helped reframe national health policy by expanding programs that address child marriage and support married girls and extremely isolated young girls, many of whom are migrants in domestic service in Ethiopia's towns and cities. Our portfolio of research represents a groundbreaking global effort to improve programs and policies for girls as a core development strategy.

In this year's report, Council vice president Ann Blanc writes about rigorous program evaluation as the cornerstone of our work with adolescent girls. Applying science to address global challenges-identifying problems, creating and testing strategies, evaluating their impact, and using our findings to refine and improve programs-is how the Council has led the way for sixty years. With this approach, we deliver solutions that improve lives around the world.

Our work to document the lives of girls, give them a say in their own lives, and learn what will put them on the path to healthy, productive adulthood would not be possible without the steadfast involvement and enthusiasm of our donors, partners, and trustees. We are deeply grateful for your generosity. With your support, we look forward to continuing to help women, men, and children around the world lead lives of satisfaction and purpose. 


\section{PURSUING THE EVIDENCE, PUSHING THE BOUNDARIES}

BY ANN K. BLANC

There are more than 500 million adolescent girls in the developing world. Fifteen years ago, the Population Council's landmark publication, The Uncharted Passage, demonstrated the key role these girls play in the health and development of their families, communities, and the world. The book also documented a gap in knowledge about girls' lives and a lack of thoughtful evidence-based programs. The Council's contributions galvanized efforts to gather evidence on ways to empower girls and enhance their lives.

We believe that if we improve girls' health, keep them safe and in school, and give them critical information, a say in their own lives, and a strong network of support, they will prosper. Our beliefs are based on rigorous scientific analysis of interventions the Council and others have conducted to help girls lead more productive lives. When girls stay in school, they gain skills and knowledge, avoid the disadvantages of early childbearing, and have more earning power. A World Bank study has shown that excluding adolescent girls from school, community participation, and meaningful livelihoods has a substantial negative impact on economic growth.

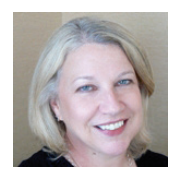

Ann K. Blanc is a Population Council vice president and director of the Poverty, Gender, and Youth program. Her research focuses on adolescent sexual and reproductive health, maternal health, gender and power dynamics, and fertility trends and patterns.

The Population Council is at the forefront of research, policy analysis, and program design for adolescent girls in the developing world. We have conducted research that identifies which girls are the most vulnerable and where they are geographically concentrated. We have illuminated the scope and negative impact of child marriage. We have shown that programs often don't reach the most vulnerable girls. And we have 

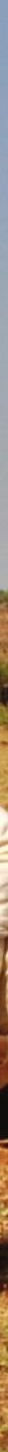

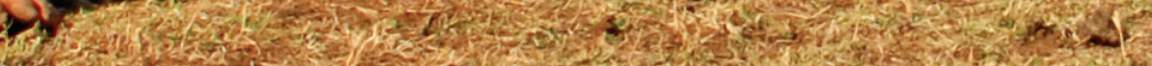

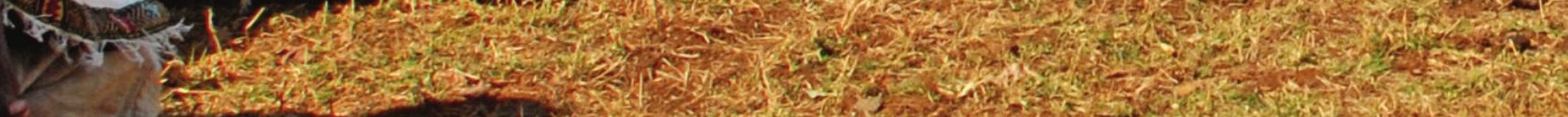

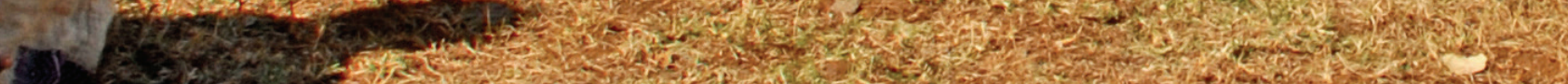

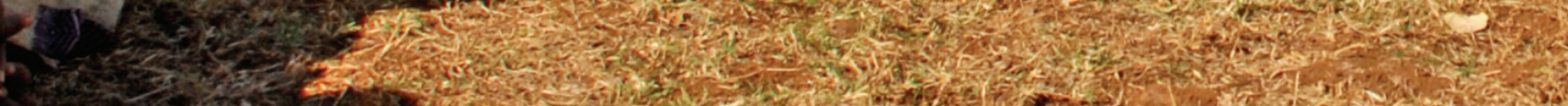
(1)

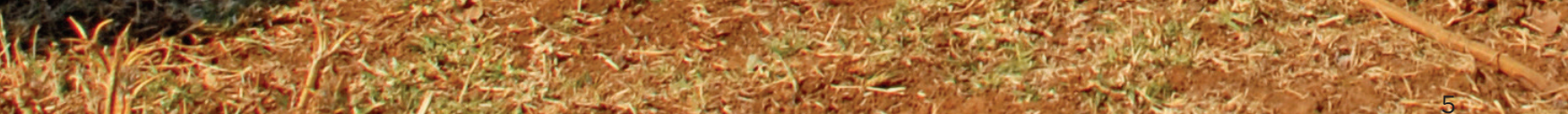

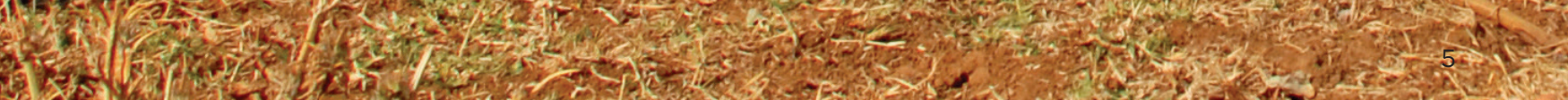

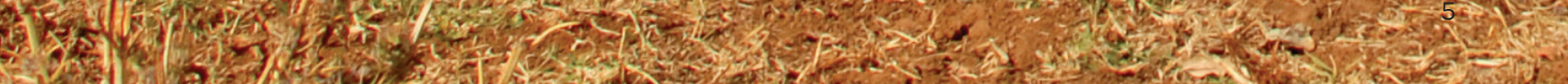





\section{THE POPULATION COUNCIL HAS THE}

LARGEST BODY OF RESEARCH

EVALUATING PROGRAMS TO IMPROVE

\section{THE LIVES OF ADOLESCENT GIRLS}

LOCATIONS OF OUR RANDOMIZED,

CONTROLLED TRIALS AROUND THE WORLD

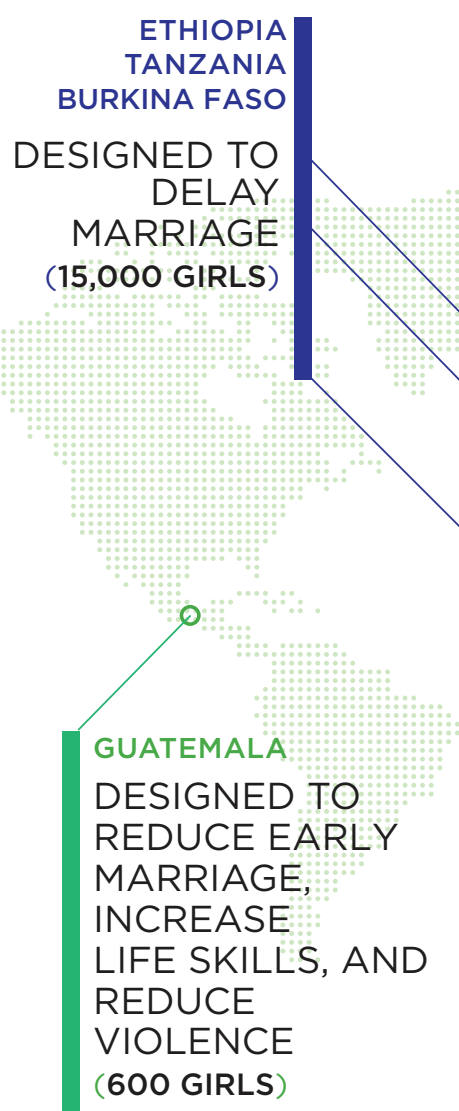

ETHIOPIA

DESIGNED TO

MARRIAGE

(15,000 GIRLS)

UATEMALA

DESIGNED TO

REDUCE EARLY

MARRIAGE

INCREASE

LIFE SKILLS, AND

REDUCE

VIOLENCE

(600 GIRLS)
BANGLADESH

DESIGNED TO

REDUCE

EARLY MARRIAGE AND VIOLENCE

AGAINST WOMEN

AND GIRLS

(18,500 GIRLS)
DESIGNED TO SUPPORT

SECONDARY

EDUCATION

4,500 GIRLS

\section{列}

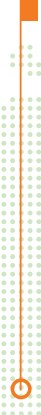

ZAMBIA

DESIGNED TO

REDUCE EARLY

MARRIAGE,

SEXUALLY

TRANSMITTED

INFECTIONS, AND

UNINTENDED

PREGNANCY

(4,000 GIRLS) 
THE POPULATION

COUNCIL IS

CONDUCTING

RANDOMIZED,

CONTROLLED TRIALS

TO MEASURE THE

EFFECTIVENESS

OF VARYING

COMBINATIONS OF

SOCIAL, ECONOMIC,

AND HEALTH

COMPONENTS FOR

ADOLESCENT GIRLS.

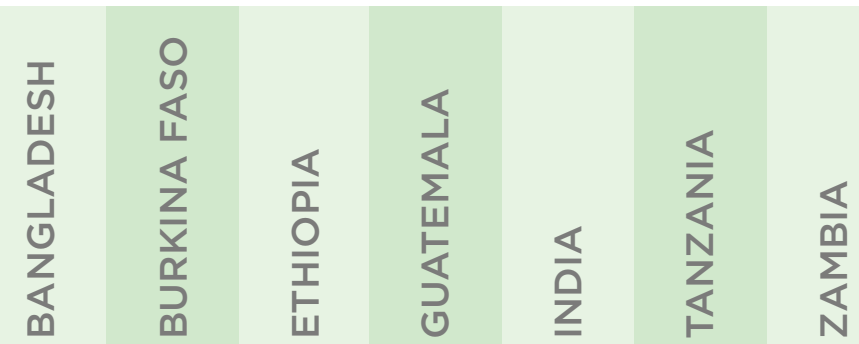

SOCIAL

COMMUNITY AWARENESS-RAISING

SAFE SPACES TO MEET WITH FRIENDS/MENTORS

SCHOOL
IMPROVEMENTS

ECONOMIC

LIVELIHOODS

TRAINING

LEGAL AID

SERVICES

SAVINGS

ACCOUNTS

\begin{tabular}{r|r|r|r|}
\hline SCHOOL SUPPLIES \\
AND LIVESTOCK \\
\hline FINANCIAL \\
LITERACY
\end{tabular}




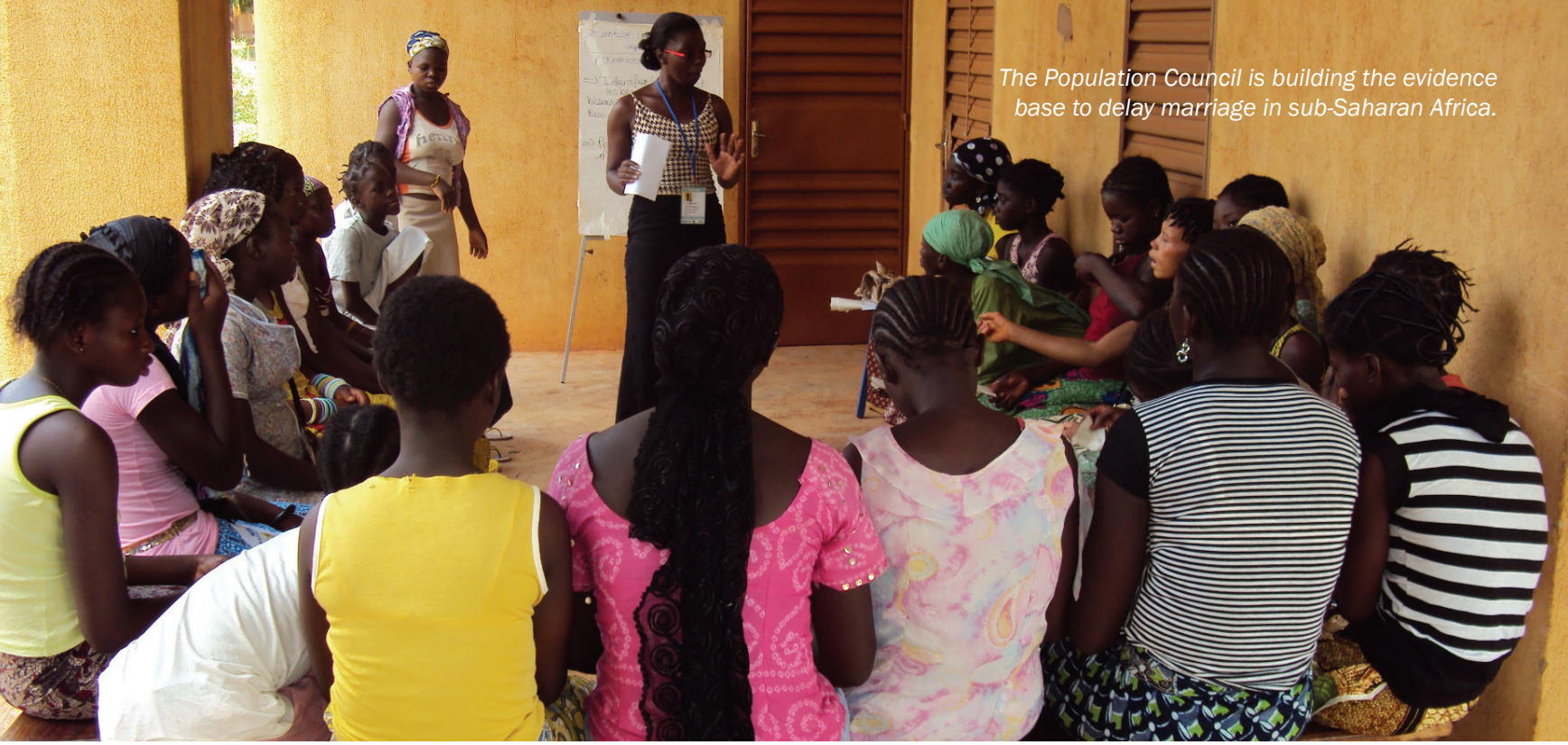

awareness-building, school supplies, livestock, and mentors and supported married girls with information about reproductive health and family planning. An evaluation found that girls aged 10-14 who participated in the program were 90 percent less likely to be married at the end of the program than girls who did not, and three times more likely to be in school. Married girls in the program were three times more likely to be using family planning methods compared to other married girls. The work led to greater attention to early marriage and increased investment in initiatives to delay marriage and support girls who are already married. We decided to delve deeper and determine which component of the program was most critical to its success. So we recently launched an expanded investigation in Ethiopia and other countries to determine the most effective elements of this approach.

We will find out which programs-and which of their key elements-do the most to help girls stay in school and avoid unwanted sex, child marriage, early and unintended pregnancy, HIV and STI infection, and gender-based violence. These studies will allow us to discover what knowledge and skills given to a girl make the biggest difference in the life of the woman she becomes.

Robust program evaluation takes time. Getting solid answers will take years, not months. But by pursuing the evidence, we will identify best practices, refine the critical elements of girl-centered programs, and eliminate ineffective approaches.

A few years from now, we will have an even richer trove of evidence that we and others will use to improve and advance girlcentered programs. As we always have, we will share information with governments, advocates, policymakers, researchers, nongovernmental organizations, and community organizations about what works to empower girls, help them gain an education and cultivate savings, and improve their sexual and reproductive health. With this knowledge, we can build local capacity to expand and deliver these programs to vulnerable adolescent girls.

We will continue to pursue the evidence and change the expectations of policymakers, communities, families, and girls themselves about girls' potential. 


\section{THE POPULATION COUNCIL CONDUCTS BIOMEDICAL, SOCIAL SCIENCE, AND PUBLIC HEALTH RESEARCH. WE DELIVER SOLUTIONS THAT LEAD TO MORE EFFECTIVE POLICIES, PROGRAMS, AND TECHNOLOGIES THAT IMPROVE LIVES AROUND THE WORLD.}

\section{TACKLING TOUGH CHALLENGES}

The Population Council's Poverty, Gender, and Youth program seeks to understand and address the social dimensions of poverty, the causes and consequences of gender inequality, the disparities in opportunity that arise during adolescence, and the critical requirements for reaching a successful, productive adulthood in developing countries.

Our HIV and AIDS program is devoted to understanding and slowing the spread of the HIV epidemic. Through biomedical and behavioral research, we expand access to innovative and effective products and services.

Our Reproductive Health program strives to improve sexual and reproductive health, especially for vulnerable people in developing countries. We help individuals to achieve their family planning and reproductive health goals through improvements in technologies and services. We work to reduce maternal mortality and morbidity.
Established in 1952, the Population Council is governed by an international board of trustees. Its New York headquarters supports a global network of country offices. The Council staff consists of more than 570 women and men from 31 countries. More than 60 percent are based outside the United States. Council staff members conduct research and carry out programs in 50 countries.

\section{DELIVERING SOLUTIONS}

Population Council staff identify neglected health and development problems; work with developing-country partners to design, implement, and test pilot programs to address these challenges; conduct biomedical research to develop new contraceptives and microbicides; inform policymakers, program managers, the scientific community, and the public about the results of our research; participate with governments and nongovernmental organizations to expand successful pilot programs and to improve largescale programs; and collaborate with pharmaceutical companies to ensure that our products are available to the poorest and most vulnerable people worldwide. 


\section{SHARING KNOWLEDGE}

The Population Council publishes two widely read and influential peer-reviewed scientific journals: Population and Development Review and Studies in Family Planning. The Council also maintains a website and produces and disseminates books, working papers, newsletters, reports, slide shows, software, and toolkits. A database of our publications is provided at www.popcouncil.org/pubsearch.

\section{IMPROVING PROGRAMS}

The Population Council's work does not end with conducting research. We strive to ensure that our findings get translated into concrete improvements in policies and programs. We provide technical assistance to strengthen national programs, and we offer expertise in expanding effective and sustainable interventions, implementing systems to monitor and evaluate projects, and finding innovative ways to pay for the costs of care.

\section{STRENGTHENING RESOURCES}

The Population Council helps to improve the research capacity of biomedical, public health, and social science researchers in developing countries through grants, fellowships, apprenticeships, and support to research centers. The Council's fellowship programs have helped advance the careers of thousands of social and biomedical scientists, public health researchers, and program managers, many of whom have gone on to hold leadership positions. In 2012, we supported 18 fellows.

\section{FORMING PARTNERSHIPS}

Achieving our ambitious mission is only possible in partnership with governments, universities, foundations, pharmaceutical companies, public and private health networks, hospitals, research centers, nongovernmental organizations, and individuals from around the world. These partnerships represent one of the most influential ways in which we improve services and create lasting change. Through our partnerships, we support sound practices and efforts to increase the scope of highly effective programs. 

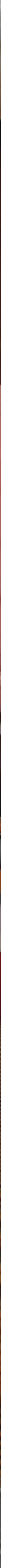


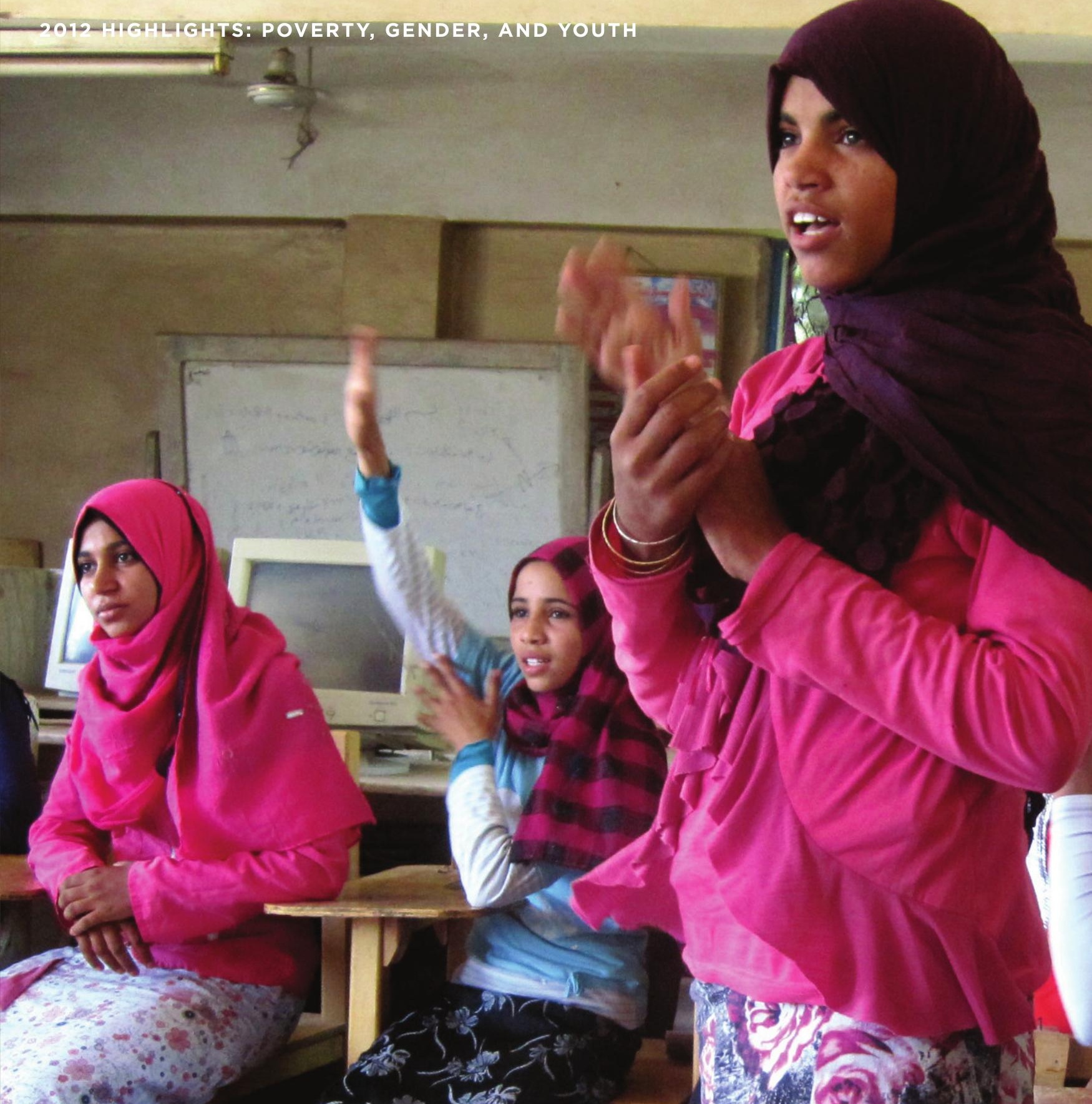

\section{CHANGING ATTITUDES ABOUT GENDER ROLES IN EGYPT}

The Population Council's Ishraq ("Sunrise") program provides 12-15-year-old out-of-school girls in rural Upper Egypt-the least developed and most economically disadvantaged region of the country-with mentors and safe spaces for informal learning and sports participation. The program, launched in 2001 , is the Council's original girls' empowerment initiative. A 2012 evaluation of its scale-up phase found impressive, statistically significant improvements for participating girls: 88 percent of Ishraq girls are able to write their sibling's name, compared to 36 percent of girls in the control group; one-third of Ishraq girls plan to pursue further education, compared to 5 percent of control girls; and 71 percent of Ishraq girls have more than one non-relative friend, compared to 44 percent of control girls. Ishraq also improved parents' and brothers' attitudes toward gender equality, girls' participation in decisionmaking, girls' mobility, and sports for girls. 


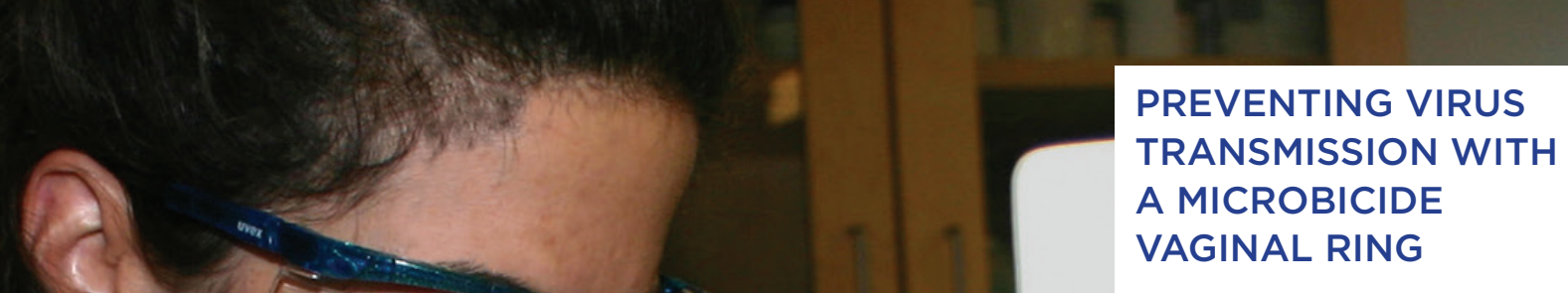

In 2012, a Population Council study provided the first efficacy data showing that an anti-HIV vaginal ring can prevent infection in animals, and indicated strong potential for the success of such rings in women. Scientists found that a vaginal ring releasing MIV-150, an anti-HIV drug, can prevent the transmission of SHIV in macaque monkeys. SHIV is a virus combining genes from HIV and SIV (the monkey version of HIV). The study was featured on the cover of the journal Science Translational Medicine. Macaques received either MIV-150 vaginal rings or placebo vaginal rings and were exposed to a single dose of SHIV. This proof-ofconcept study demonstrated that investment in vaginal rings as an HIV-delivery system may eventually provide tangible health benefits.

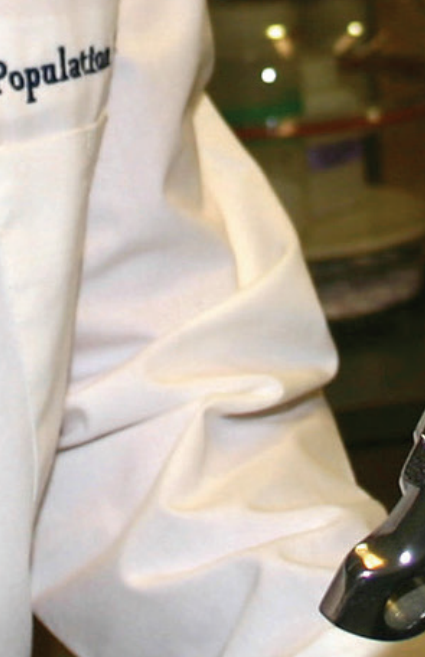




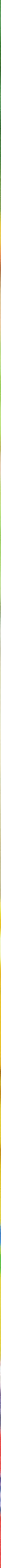

\section{INCREASING ACCESS TO LONG-ACTING REVERSIBLE CONTRACEPTION}

In May 2012, working with the International Federation of Gynecology and Obstetrics and the Reproductive Health Supplies Coalition, the Population Council generated an action plan to improve access to highly effective, long-acting reversible contraceptives (LARCs) by increasing provider training and awareness and working with drug companies and donors to reduce costs. LARCs were a key focus of the July 2012 London Summit on Family Planning, which promoted a goal of enabling 120 million more women and girls to have access to high-quality family planning information and services by 2020. In September, the Jadelle Access Program was formed with support from a number of organizations and governments to make Jadelle ${ }^{\circledR}$-a Council-developed two-rod levonorgestrel contraceptive implantavailable to more than 27 million women. Throughout the year, the Council made progress toward submitting a New Drug Application to the FDA for a new LARC, our one-year contraceptive vaginal ring.

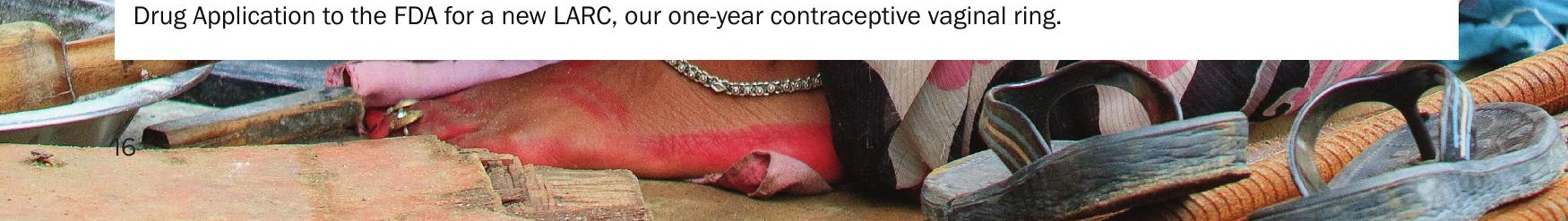


The Population Council and its Africa Regional Sexual and Gender-Based Violence (SGBV) Network achieved key successes in 2012. The governments of South Africa and Zambia issued their countries' first-ever policies to address sexual and gender-based violence, which were informed by the Population Council's research and recommendations. These policies reflect a comprehensive model of care to provide medical management of SGBV, involve the criminal justice system, and engage communities to prevent SGBV. The Government of Zambia is expanding police provision of emergency contraception to victims of rape, and the Government of Malawi is testing this approach. In December, Ministers of Health from Kenya, Lesotho, Malawi, Mauritius, Seychelles, Swaziland, Tanzania, Uganda, Zambia, and Zimbabwe passed a resolution allowing all women seeking maternal health services to be screened for intimatepartner violence using the screening tool developed by the Population Council. 


\section{FINANCIAL REPORT}

We are pleased to report that the Population Council's revenue increased by more than 12.5 percent, from $\$ 64.4$ million in 2011 to $\$ 72.6$ million in 2012. This increase helps maintain the Council's financial health and ensures that we have the resources to continue our vital work.

The charts on this page provide details on the Council's sources of support and use of funds. The Council's program spending ratio, a key financial indicator, was 83 percent for fiscal 2012. For every dollar spent, 83 cents goes directly to research and program activities, demonstrating our commitment to our mission.

We closely monitor the Council's financial status and remain committed to the fiscal discipline necessary to maintain our record of accomplishments. Readers interested in learning more about the Council's finances can consult http://popcouncil.org/who/financials.asp

\section{SOURCES OF SUPPORT TOTAL \$72.6 MILLION}

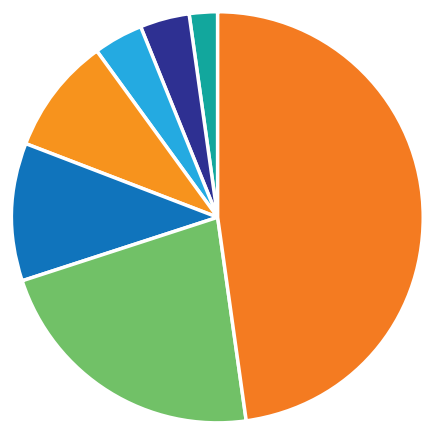

U.S. GOVERNMENT

$48 \%$

FOUNDATIONS, CORPORATIONS, NONGOVERNMENTAL

ORGANIZATIONS,

AND INDIVIDUALS

$22 \%$

INVESTMENT RETURNS $\quad 11 \%$

ROYALTIES $\quad 9 \%$

INTEREST AND DIVIDENDS $4 \%$

OTHER GOVERNMENTS $\quad 4 \%$

MULTILATERAL ORGANIZATIONS

$2 \%$

USES OF FUNDS

TOTAL \$78.2 MILLION

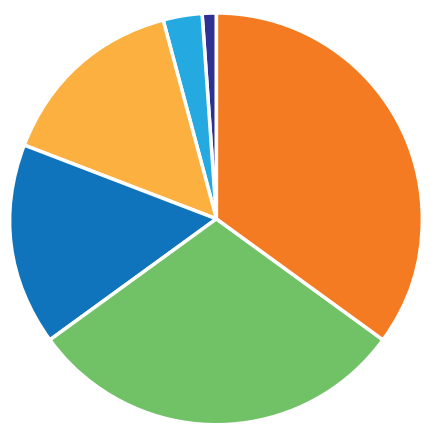

REPRODUCTIVE HEALTH

$35 \%$

HIV AND AIDS

$30 \%$

MANAGEMENT AND GENERAL

$16 \%$

POVERTY, GENDER, AND YOUTH

$15 \%$

OTHER PROGRAM SERVICES

$3 \%$

FUNDRAISING

$1 \%$ 
STATEMENT OF ACTIVITIES (FOR THE YEAR ENDED DECEMBER 31, 2012)

\begin{tabular}{|c|c|c|c|c|c|c|}
\hline & \multicolumn{3}{|c|}{ Unrestricted } & \multicolumn{3}{|c|}{ Restricted } \\
\hline & $\begin{array}{r}\text { General } \\
\text { undesignated }\end{array}$ & $\begin{array}{r}\text { The John D. } \\
\text { Rockefeller 3rd } \\
\text { Memorial Fund } \\
\text { and others }\end{array}$ & Total & $\begin{array}{l}\text { Temporarily } \\
\text { restricted }\end{array}$ & $\begin{array}{l}\text { Permanently } \\
\text { restricted }\end{array}$ & Total \\
\hline \multicolumn{7}{|l|}{ OPERATING REVENUE } \\
\hline Grants and contributions & $\$ 54,214,914$ & 3,800 & $54,218,714$ & $1,018,073$ & - & $55,236,787$ \\
\hline Royalties & $6,549,529$ & - & $6,549,529$ & - & - & $6,549,529$ \\
\hline $\begin{array}{l}\text { Interest and dividends (net of } \\
\$ 189,112 \text { investment fees) }\end{array}$ & 19,393 & $2,097,771$ & $2,117,164$ & 498,326 & - & $2,615,490$ \\
\hline $\begin{array}{l}\text { Net appreciation (depreciation) } \\
\text { in fair value of investments }\end{array}$ & $(58,887)$ & 6,967,192 & $6,908,305$ & $1,256,033$ & - & $8,164,338$ \\
\hline Other & 68,416 & - & 68,416 & - & - & 68,416 \\
\hline Net assets released from restrictions & $9,729,750$ & - & $9,729,750$ & $(9,729,750)$ & - & - \\
\hline TOTAL OPERATING REVENUE & $70,523,115$ & $9,068,763$ & $79,591,878$ & $(6,957,318)$ & - & $72,634,560$ \\
\hline \multicolumn{7}{|l|}{ OPERATING EXPENSES } \\
\hline \multicolumn{7}{|l|}{ Program services } \\
\hline HIV and AIDS & $23,677,392$ & - & $23,677,392$ & - & - & $23,677,392$ \\
\hline Poverty, Gender, and Youth & $11,891,507$ & 21,399 & $11,912,906$ & - & - & $11,912,906$ \\
\hline Reproductive Health & $26,730,095$ & 567,015 & $27,297,110$ & - & - & $27,297,110$ \\
\hline Distinguished Colleagues & 374,867 & - & 374,867 & - & - & 374,867 \\
\hline Publications & $1,584,530$ & - & $1,584,530$ & - & - & $1,584,530$ \\
\hline TOTAL PROGRAM SERVICES & $64,258,391$ & 588,414 & $64,846,805$ & - & - & $64,846,805$ \\
\hline \multicolumn{7}{|l|}{ Supporting services } \\
\hline Management and general & $12,416,818$ & 384,760 & $12,801,578$ & - & - & $12,801,578$ \\
\hline Fundraising & 544,165 & - & 544,165 & - & - & 544,165 \\
\hline TOTAL SUPPORTING SERVICES & $12,960,983$ & 384,760 & $13,345,743$ & - & - & $13,345,743$ \\
\hline TOTAL OPERATING EXPENSES & $77,219,374$ & 973,174 & $78,192,548$ & - & - & $78,192,548$ \\
\hline $\begin{array}{l}\text { (Deficiency)/excess of operating } \\
\text { revenue over operating expenses }\end{array}$ & $(6,696,259)$ & $8,095,589$ & $1,399,330$ & $(6,957,318)$ & - & $(5,557,988)$ \\
\hline \multicolumn{7}{|l|}{ Other changes in net assets: } \\
\hline $\begin{array}{l}\text { Gain on lease obligation and other, } \\
\text { net }\end{array}$ & 390,555 & - & 390,555 & - & - & 390,555 \\
\hline \multicolumn{7}{|l|}{$\begin{array}{l}\text { Pension and other postretirement } \\
\text { charges other than net periodic } \\
\text { benefit cost }\end{array}$} \\
\hline Transfer from endowments & $5,325,180$ & $(4,540,337)$ & 784,843 & $(784,843)$ & - & - \\
\hline DECREASE IN NET ASSETS & $(556,737)$ & $3,555,252$ & $2,998,515$ & $(7,742,161)$ & - & $(4,743,646)$ \\
\hline \multicolumn{7}{|l|}{ NET ASSETS AT BEGINNING } \\
\hline OF YEAR & $4,703,557$ & $70,460,681$ & $75,164,238$ & $23,242,324$ & $5,485,776$ & $103,892,338$ \\
\hline NET ASSETS AT END OF YEAR & $\$ 4,146,820$ & $74,015,933$ & $78,162,753$ & $15,500,163$ & $5,485,776$ & $99,148,692$ \\
\hline
\end{tabular}

Restricted 


\section{ASSETS}

Cash and cash equivalents

Grants and contributions receivable, net

U.S. government agencies

$7,256,178$

Other

Other receivables

Prepaid expenses and other assets

Postretirement medical benefits trust

$5,323,351$

Investments

$94,454,435$

Fixed assets, net

$6,115,146$

TOTAL ASSETS

\section{LIABILITIES AND NET ASSETS}

Liabilities

Accounts payable, accrued expenses, and other liabilities

$\$ 6,200,620$

Awards, contracts, and fellowships payable

$3,598,018$

Program advances

$9,842,653$

Loan payable

$1,506,000$

Deferred rent credit

791,137

Accrued lease obligation

493,066

Postretirement medical benefits payable

Net assets

Unrestricted

General undesignated

The John D. Rockefeller 3rd Memorial Fund and others

SUBTOTAL UNRESTRICTED

Restricted

Temporarily restricted

Permanently restricted 


\section{SOURCES OF SUPPORT}

Funding for the Population Council's work was generously provided by the government agencies, multilateral organizations, foundations, corporations, and individuals listed here. This support allows the Council to deliver solutions to critical health and development challenges and improve lives. We greatly appreciate all contributions and thank our donors for their support.

\section{GOVERNMENTS AND GOVERNMENTAL AGENCIES \\ Government of the \\ Netherlands \\ - Embassy of the Kingdom of the Netherlands \\ Government of Sweden \\ - Swedish International Development Cooperation Agency \\ - Swedish Ministry for Foreign Affairs \\ Government of the \\ United Kingdom \\ - Department for International Development (DFID)}

Government of the United

States

- Agency for International Development (USAID)

- Centers for Disease Control and Prevention (CDC)

- National Institutes of Health (NIH)

\section{MULTILATERAL}

\section{ORGANIZATIONS}

Global Network of People Living with HIV/AIDS (GNP+)

International Consortium for Emergency Contraception (ICEC)

Joint United Nations Programme on HIV/AIDS (UNAIDS)

Poverty and Economic Policy Research Network (PEP)

United Nations Children's Fund (UNICEF)

United Nations Development Fund for Women (UNIFEM) United Nations Foundation (UNF)

United Nations Population Fund (UNFPA)

World Bank Group

World Health Organization (WHO)
FOUNDATIONS/

CORPORATIONS/

OTHER

NONGOVERNMENTAL

ORGANIZATIONS

AIDS Foundation of Chicago (AFC)

Albert Einstein College of

Medicine (AECOM)

Anonymous

The Atlantic Philanthropies

Bayer Schering Pharma AG

Better World Fund

The Fred $\mathrm{H}$. Bixby Foundation

BRAC USA

Columbia University Medical

Center

Deutsche Gesellschaft

für Internationale

Zusammenarbeit GmbH

The William H. Donner

Foundation

Elton John AIDS Foundation

Emory University

EngenderHealth

Equality Now

FHI 360

The Ford Foundation

H. B. Fuller Foundation

Futures Group International, LLC

The Bill \& Melinda Gates

Foundation

Georgetown University

Girl Hub

Guttmacher Institute

Harvard School of Public

Health

Health Decisions

The William and Flora

Hewlett Foundation

HRA Pharma

Institute of International

Education

International Centre for

Diarrhoeal Disease

Research, Bangladesh (icddr,b)

International Development

Research Centre (IDRC)

International Food Policy

Research Institute (IFPRI)

International Planned

Parenthood Federation

(IPPF)
International Rescue

Committee (IRC)

IntraHealth

Henry M. Jackson

Foundation for the

Advancement of Military

Medicine

Jacobs Foundation

John Snow, Inc./JSI Research and Training Institute, Inc.

The Johns Hopkins University Levi Strauss \& Co.

Foundation

London School of Hygiene \& Tropical Medicine (LSHTM)

The John D. and Catherine T. MacArthur Foundation

Magee-Women's Research Institute and Foundation (MWRIF)

Marie Stopes International (MSI)

New York University (NYU)

Nike Foundation

NoVo Foundation

Overseas Development Institute (ODI)

The David \& Lucile Packard

Foundation

Partridge Foundation

The Passport Foundation

Plan International

Population Reference Bureau (PRB)

Population Services International (PSI)

Program for Appropriate Technology in Health (PATH)

Public Health Foundation of India (PHFI)

Research \& Advocacy Fund (RAF) of the British Council

Research Triangle Institute International (RTI)

Society for Family Health (SFH)

Solutions for Innovative Policies, Programs and Technologies

Summit Foundation Inc.

Syria Trust for Development

Teva Pharmaceuticals

University of California at San Diego

University of California at San Francisco
University of Connecticut Health Center

University Research Co., LLC ViiV Healthcare

INDIVIDUAL DONORS AND

FAMILY FOUNDATIONS

John D. Rockefeller 3rd

Visionaries

Anonymous (2)

Avis and Clifford Barrus

Medical Foundation

Mr. Jerry Cunningham and Ms. Diane Cunningham*

Mr. Kenneth Edlow and Dr. Mary Edlow

George and Patricia Ann

Fisher Foundation

F. M. Kirby Foundation

Millstream Fund*

Stavros Niarchos Foundation

The Blanchette Hooker

Rockefeller Fund

The Shenandoah

Foundation*

Seymour and Kate Weingarten

President's Laureates

Anonymous (7)

Tammy Allen and Daniel Gropper

D. Euan Baird and Angelica Baird

Willard B. Brown

George P. and Ching-Ching Cernada*

C. S. Craig Family Foundation

Peter J. and Nancy

Donaldson*

Barbara B. Ebert*

Andrea and Brian Edlow

Elizabeth Fielding Edlow and Larry Clarke

Gary and Kristin Friedman

Robert W. Gillespie

Sallie T. Gouverneur

Alva Greenberg

JJJ Charitable Foundation

Sukey N. Wagner*

Dr. Rena J. Zieve and

Dr. Greg J. Kuperberg* 
Council Champions

Anonymous (9)

Sandra P. and

Lawrence Arnold*

Michael Baird

Milton Barber

Ann Blanc

Thomas S. Blount

Andrew Boas*

John and Zenaida Bongaarts

Caithness Foundation, Inc

Paul Demeny

Judith Diers

Eco Trust

Andrea Eschen

Rosemary Faulkner

Glen M. Feighery*

Mary Geissman

David Grill

Angel Gurria

Elizabeth A. Hallin

Paul C. Haughey*

The William W. Hildreth Fund

of Fidelity Investments

Jerrold W. Huguet

April A. Johnson

Kaplan Sisters Foundation

Kyung Ja Kim*

Margaret A. Knoll

Wayne V. Krill

George Krumme

Joanne Lyman

McBride Family \& Aspen

Airport Business Center

Foundation

John M. and Renate E.

Mirsky

Carol and Daniel Mishell, Jr.

Samarendranath and Rekha Mitra*

Ursula and Paul Ofman

Wanda J. Olson

Barbara E. Parish

Mary Catherine Phinney

Marnie S. Pillsbury

Lyle H. Ramshaw*

James $\mathrm{H}$. and Amy H. Regan

Alison J. Renner

Thomas L. Richie and Diane

Pascal*

Julie A. Robichaud*

David Rockefeller*

Betsy and John Rolls*

Matthew Rutenberg*

Naomi Rutenberg*

James E. Sailer and Cass

Conrad*

Frederick $\mathrm{H}$. and Nancy Link Schmidt*

Cherida C. Smith*

Jane N. Spragg*
Karen Steel

Sue S. Stewart*

Katy R. Stokes and David C.

Esseks

Te-Hsiung Sun

Claire Higham Thomas and

Rees D. Thomas

Miklos and Elena Toth

Judith C. and John W.

Townsend

Ramachandra Tummala

United Way of Rhode Island

Lucy R. Waletzky*

Daniel A. Weisberg and

Cynthia S. Arato

Jed Weissberg and Shelley

Roth

Effie E. Westervelt*

Wreck Point Foundation, Inc.

Boniface Zaino

Suzanne C. and Paul L. Zuzelo

\section{Council Innovators}

Anonymous (7)

Rosalind S. Abernathy

Donald J. and Dena C.

Abrams

Joel W. Ager*

Mar Aguilar

Timothy S. and Anne M. Allen

Jill Alonzo

Sandra D. and Ethan D.

Alyea, Jr.*

Enrique Robledo Arnuncio

Shawky Badawy

Wendy Baldwin

Jonathan and Judith Baron*

David Bausch

Rachel G. Beck and Jeremy

Naftel

Robert Bellucci

John R. Bermingham*

Robyn Blair

Douglas H. Borsom

John W. and Claire Bossung*

Frederick and Jane Buckner

Emily Carmany

Thomas H. Clewe

J. Jarrett Clinton

Roberto Cuca

Gonzalo and Kathy

De Las Heras

Stanley F. and Elizabeth G. Dole*

Jean and George Dowdall

Kelly Edwards

Ernst and Jan Epstein

Chet Fagin

John D. and Margaret M.

Fogarty

We acknowledge with gratitude that each member of the Population Council's Board of Trustees made a gift to support the Council.

Andrew L. Frey*

Michele L. Gerber

Gorlitz Foundation, Ltd.

William M. Grady and Karen

D. Tsuchiya*

Catherine Grant

Guy Harris

Mary W. Heller

Judith Herzfeld

Jeffrey Hillhouse

Douglas W. and Barbara E. Holdridge

The Richard R. Howe

Foundation

Terence Hull

Frederick V. Iffert*

Richard S. Johnson and

May J. Reed*

Denis F. Johnston

Elise F. Jones*

Carmen Jungbluth*

Kaiser Foundation Health

Plan of the Northwest

Community

Dennis G. and Joanne G. Keith*

Brian King

Austin Lamb

Thomas A. Lehrer

Susan Levine

Katherine Lewis and

Richard A. Chasman

Daniel LoCascio

Beau Lynn-Miller

Walter H. and Ruth K.

MacGintie Fund*

Elizabeth J. McCormack*

Ruth and Irwin Merkatz

Virginia P. and Robert L.

Montgomery*

Ann and William T. Naftel

Charles B. Nam

Robert H. Palmer

Daniel K. and Susan A.

Paulien

People Potential

Scott Perry

Jan E. and Yvonne

Petersen

David Porteous and

Vicky Smith

Robert T. Porter
Ann Pugh

David M. and Ann Reynolds

Edward and Sharon Rubin

The Saint Paul Foundation

Michael Saks and Roselle

Wissler

Craig Savel

Steven Schmitt*

Jutta R. Scott*

Robert L. and Elizabeth $\mathrm{H}$. Scott*

Marianne E. Selph*

William Seltzer*

Lawrence P. Simms and

Alison G. Ho*

Walter and Susan Slowinski

Puneet Sood

Janet M. Throop*

David J. Tilles

Harriet B. Todd*

William J. and Faith M.

Towle*

George Vacek

S. Jean Van Der Tak*

Deborah Weiss and Matthew Connors

Kim S. and Kathleen W.

Wennesland*

Nancy and Mark R. Wessling*

Wichita Falls Area Community Foundation John Hirschi Donor Advised Fund*

Anne Wilkinson

Oliver and Helen M. Wolcott*

Barbara Yanni*

Alice M. Young

George and Sondra

Zeidenstein

H. Neil Zimmerman*

*Donors whose names are followed by an asterisk have contributed to the Population Council for at least five consecutive years. 


\section{BOARD OF TRUSTEES}

Mark A. Walker

Chairman

Managing Director

Rothschild

London, United Kingdom

Darcy Bradbury

Managing Director

The D.E. Shaw Group

New York, New York

Peter Brandt

Stamford, Connecticut

Howard Cox

Advisory Partner

Greylock Partners

Waltham, Massachusetts

Peter J. Donaldson

President

Population Council

New York, New York

Wafaa El-Sadr

Professor of Clinical Medicine and Epidemiology

Mailman School of Public Health

Columbia University

New York, New York
Anna Glasier

Honorary Professor

Department of Obstetrics and Gynecology

University of Edinburgh

Edinburgh, United Kingdom

Victor Halberstadt

Professor of Public Sector Economics

University of Leiden

Netherlands

Henry L. King

Senior Counsel

Davis Polk \& Wardwell

New York, New York

Charles D. Klein

Managing Director

American Securities Capital

Partners, LLC

New York, New York

Anna Mastroianni

Professor of Law

University of Washington

School of Law

Seattle, Washington

Cheikh Mbacké

Independent Consultant

Dakar, Senegal
Lauren A. Meserve

Deputy Chief Investment Officer

Metropolitan Museum of Art

New York, New York

Jotham Musinguzi

Regional Director

Partners in Population and

Development

Africa Regional Office

Kampala, Uganda

Anne R. Pebley

Professor

Department of Community Health Sciences

School of Public Health

University of California, Los Angeles

Los Angeles, California

Terry Peigh

Senior Vice President,

Managing Director

Interpublic Group of Companies

New York, New York

K. Sujatha Rao

New Delhi, India

Elizabeth Eder Zobel de Ayala

Co-founder and Chairman

Sa Aklat Sisikat Foundation, Inc.

Manila, Philippines

\section{SENIOR MANAGEMENT}

Peter J. Donaldson

President

Mar Aguilar

Director

International Support

Ann K. Blanc

Vice President

Poverty, Gender, and Youth Program

John Bongaarts

Vice President and

Distinguished Scholar

Scott Newman*

Chief Financial Officer and Treasurer
Naomi Rutenberg

Vice President

HIV and AIDS Program

James E. Sailer

Vice President

Corporate Affairs Division

John W. Townsend

Vice President

Reproductive Health Program

Patricia C. Vaughan

General Counsel and Secretary 


\section{UNITED STATES}

Headquarters

Population Council

One Dag Hammarskjold Plaza

9th Floor

New York, NY 10017 USA

Tel: +12123390500

Fax: +1 2127556052

E-mail: pubinfo@popcouncil.org

Center for Biomedical Research

Population Council

1230 York Avenue

New York, NY 10065 USA

Tel: +1 2123278731

Fax: +1 2123277678

E-mail: biomed@popcouncil.org

Washington, DC

Population Council

4301 Connecticut Avenue, NW

Suite 280

Washington, DC 20008 USA

Tel: +1 2022379400

Fax: +1 2022378410

E-mail: popcouncil@popcouncil.org

\section{INTERNATIONAL}

\section{Bangladesh}

Population Council

House CES (B) 21

Road 118

Gulshan, Dhaka, Bangladesh

Tel: +880 28821227

Fax: +880 28823127

E-mail: info.bangladesh@popcouncil.org

\section{Burkina Faso}

Population Council

Cité An III/1er Etage

Pharmacie de la Liberté

36 Avenue de la Liberté

Ouagadougou, Burkina Faso

Tel: +22650 311246

Fax: +22650311242

E-mail: info.burkinafaso@popcouncil.org

\section{Egypt}

Population Council

59 Misr-Helwan Agricultural Road, Maadi

P.O. Box 168, Maadi

Cairo, Egypt 11431

Tel: +202 25255967

Fax: +202 25255962

E-mail: info.mena@popcouncil.org

\section{Ethiopia}

Population Council

Heritage Plaza, 4th Floor

Bole Medhaneialem Road

Addis Ababa, Ethiopia

Tel: +25 116663712

Fax: +25116 663722

E-mail: info.ethiopia@popcouncil.org

Ghana

Population Council

14B Ridge Road behind MedLab Bldg.

Roman Ridge

Accra, Ghana

Tel: +233 302780711

Fax: +233 302780713

E-mail: info.ghana@popcouncil.org

Guatemala

Population Council

23 Avenida 3-45

Zona 15, Vista Hermosa 1

Guatemala City, Guatemala

01015

Main tel: +502 23692760

Alternate tel: +50252930030

Fax: +502 23692760

E-mail: info.guatemala@popcouncil.org

India

Population Council

Zone 5A, Ground Floor

India Habitat Centre, Lodi Road

New Delhi, India 110003

Tel: +91 1124642901

Fax: +91112464 2903

E-mail: info.india@popcouncil.org

Kenya

Population Council

General Accident House

Ralph Bunche Road

Nairobi, Kenya

Tel: +254202713480

Fax: +254202713479

E-mail: info.nairobi@popcouncil.org

\section{Mexico}

Population Council

Avenida Cuauhtémoc no. 1400

Colonia Santa Cruz Atoyac

Delegación Benito Juárez

Mexico, DF

Mexico CP 03310

Tel: +52 5559998630

Fax: +52 5559998631

E-mail: info.mexico@popcouncil.org
Nigeria

Population Council

No. 16 Matemi Crescent

Utako District

Abuja, Nigeria

Tel: +23498706071

E-mail: info.nigeria@popcouncil.org

Pakistan

Population Council

House No. 7

Street No. 62, Section F-6/3

Islamabad, Pakistan

Tel: +92 518445566

Fax: +92 512821401

E-mail: info.pakistan@popcouncil.org

Senegal

Population Council

Sacré Coeur Pyrotechnie

Appartement 2ème Etage à Droite

Dakar, Ponty

Senegal 21027

Tel: +221338595300

Fax: +221338241998

E-mail: info.senegal@popcouncil.org

South Africa

Population Council

22 Lonehill Blvd Block B

Lonehill Office Park, Fourways

Johannesburg, South Africa 2062

Main tel: +27 117817590

Fax: +27 113261483

E-mail: info.joburg@popcouncil.org

Zambia

Population Council

Plot \#3670 No. 4 Mwaleshi Road

Olympic Park

Lusaka, Zambia 10101

Main tel: +260 211295925

Fax: +260 211295925

E-mail: info.zambia@popcouncil.org 
www.popcouncil.org/ar2012

\section{Photos}

Cover/page 1 Zambia/Natalie Jackson

Page $3 \quad$ United States/Ashish Bajracharya

Pages 5/12 Ethiopia/Zeleman Productions

Page $6 \quad$ Guatemala/Phil Borges

Page 9 Burkina Faso/Gisèle Kaboré

Page $13 \quad$ Egypt/Hanan Tammam

Page $14 \quad$ United States/Karen Tweedy-Holmes

Page $15 \quad Z a m b i a /($ Richard Lord

Page 16 India/( Brianna May

Page 17 Zambia/Jason Larkin, Panos

(c) 2013 The Population Council, Inc.

Library of Congress Catalog Number 78-617856 ISSN 0361-7858 


\section{www.popcouncil.org}

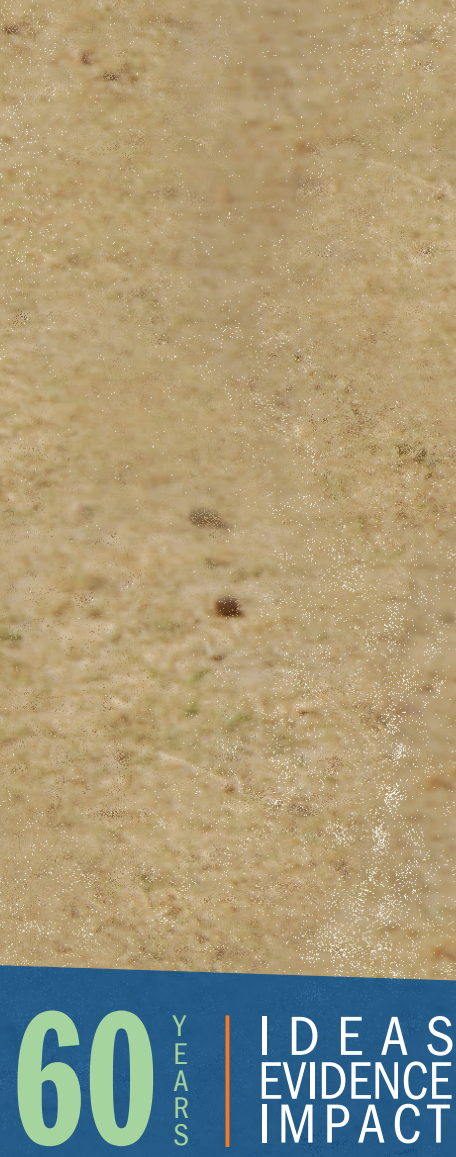

The Population Council confronts critical health and development issues-from stopping the spread of HIV to improving reproductive health and ensuring that young people lead full and productive lives. Through biomedical, social science, and public health research in 50 countries, we work with our partners to deliver solutions that lead to more effective policies, programs, and technologies that improve lives around the world. Established in 1952 and headquartered in New York, the Council is a nongovernmental, nonprofit organization governed by an international board of trustees.

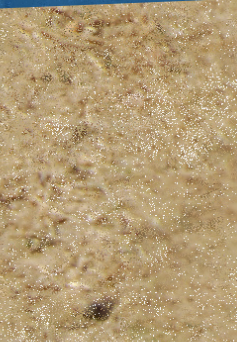

